\title{
JEWISH MEMORIAL HERITAGE OF SMALL CITIES IN THE CAPITAL SOCIO-GEOGRAPHICAL REGION OF UKRAINE
}

\author{
Maryna MYKHALIUK \\ Taras Shevchenko National University of Kyiv, Ukraine \\ marina_mikhaliuk@ukr.net
}

\begin{abstract}
Burial sites and places of memory are important sights of the past. Their current state reflects the attitude of contemporary generations to the history of the family in particular and to the history of the nation and the country as a whole. These objects can serve as a resource for the development of various types of tourism, including religious, pilgrimage, cognitive, ethnographic, genealogical, dark tourism etc. There are a large number of Jewish mass graves and places of memory of the Holocaust victims in Ukraine, which can be considered as historical and cultural component of the regional ethnocultural potential. The goal of the article is to evaluate the current state of mass graves and places of memory of the Holocaust victims in small towns in the Capital socio-geographical region of Ukraine as a component of the ethnocultural potential of the region.

The article reveals the importance of the mass graves and places of memory of the Holocaust victims in small towns in the Capital socio-geographical region of Ukraine both as a part of historical memory and as a component of the ethnocultural potential of the region. The historical preconditions of appearance of mentioned objects on the investigated area are considered. The present state of the mass graves and the places of memory of the Holocaust victims in the researched towns is analysed. The author proposes key approaches to protect and memorialize Jewish mass graves and places of memory of the Holocaust victims in Ukraine, emphasizing that honouring the memory of the victims is a necessary symbol for present and future generations. However, the embodiment of the ethnocultural potential might serve as a competitive advantage in the development of tourism and may result in the improvement of the socio-economic situation in the region.
\end{abstract}

Key words: places of memory, mass graves, Holocaust, small towns, historical memory, ethnocultural potential.

DOI: https://doi.org/10.17721/2413-7154/2018.79.42-48

UDC: $911.3: 008$

Received: March 23, 2018.

Revised: May 04, 2018.

Accepted: May 17, 2018.

\section{ЄВРЕЙСЬКА МЕМОРІАЛЬНА СПАДЩИНА МАЛИХ МІСТЕЧОК СТОЛИЧНОГО СУСПІЛЬНО-ГЕОГРАФІЧНОГО РАЙОНУ УКРАЇНИ}

\author{
Марина МИХАЛюК \\ Київський національний університет імені Тараса Шевченка, Україна \\ marina_mikhaliuk@ukr.net
}

Анотація: Традиційна культура певного етносу виступає туристичним ресурсом для розвитку різних видів і форм туризму. Ці ресурси можна поділити на наявні, які можуть бути продемонстровані, та латентні, які були притаманні етносам, що мешкали на даній території, а сьогодні від тих часів залишилися не стільки матеріальні артефакти, скільки згадки і спомини. Важливе місце у визначенні латентних ресурсів відіграє історична пам'ять - не стільки масове знання про минуле, скільки сприйняття минулого як спадщини.

Важливими пам'ятками минулого, стан яких відображає ставлення сучасників до історії родини, нації, країни загалом, є захоронення та місця пам'яті. Меморіальна спадщина охоплює як матеріальні, так і нематеріальні об'єкти, що є складовими етнокультурного потенціалу певної території. В межах малих містечок досліджуваного району існує велика кількість єврейських масових поховань та місць пам'яті жертв Голокосту. Після окупації Й. Сталіним у 1941 р. міжвоєнних польських та румунських територій, кількість євреїв в УРСР зросла щонайменше до 2,45 млн осіб. Однак напад Німеччини на Радянський Союз призвів до величезної трагедії єврейства, що отримала назву Голокост - убивство єврейського населення різних країн Європи, яке скоїла нацистська, гітлерівська Німеччина за допомогою представників інших окупованих країн у роки Другої світової війни.

Метою статті $є$ оцінка сучасного стану масових поховань та місць пам'яті єврейського етносу малих містечок Столичного суспільно - географічного району України як складової етнокультурного потенціалу регіону. У статті розкрито значення масових поховань та місць пам'яті жертв Голокосту у малих містечках Столичного суспільно-географічного району України як складової історичної пам'яті та компоненту етнокультурного потенціалу регіону. Розглянуто історичні передумови появи вищезгаданих об'єктів на території досліджуваного району. Проаналізовано сучасний стан масових поховань та місць пам'яті жертв Голокосту в зазначених містечках. Запропоновано основні шляхи з захисту та меморіалізації місць масових поховань євреїв України в роки Другої світової війни. Вшанування пам'яті жертв Голокосту $\epsilon$ необхідним символом для теперішніх та майбутніх поколінь, а реалізація етнокультурного потенціалу здатна виступати конкурентною перевагою розвитку туризму в регіоні.

Ключові слова: місця пам'яті, масові поховання, Голокост, малі містечка, історична пам'ять, етнокультурний потенціал. 
Introduction. The attitude of contemporary society to the history of the family, the nation, and the country as a whole is represented by the state of burial sites and places of memory. The burial sites include graves, cemeteries and mass graves. Depending on the combination of value characteristics, such places can serve as a resource for the developmentofvarioustypes oftourism, includingreligious, pilgrimage, cognitive, ethnographic, genealogical, dark tourism etc. [20, p. 137]. The places of memory have a great importance. According to philosopher P. Nora, these are the places in which memory is crystallized, in which it finds a refuge. This place is associated with this specific moment in history, a turning point in which a sense of rapture with the past is inextricably bound up with a sense that a rift has occurred in memory [4, p. 59].

There are a large number of the Jewish mass graves and places of memory of the victims of the Holocaust in Ukraine, which are historical and cultural component of the ethnocultural potential of the region. Together with other components that form the structure of such potential, they can be practically implemented in many directions, such as support and development of ethnic groups, improvement of international and interregional (economic, cultural, informational) relationship with other peoples similar in ethnic, cultural, religious features, tourism development, preservation of material heritage, development of infrastructure, utilities, transport system of the territory etc. [15, p. 88].

Literature Review. The aforementioned issue was investigated by many researchers, above all, by psychologists, philosophers, historians, anthropologists, ethnographers, sociologists and other scholars. At the same time, within the framework of social geography, the study of mass graves and places of memory of the Holocaust victims as a resource for the development of tourism is insufficiently explored. The essence of burial sites as a tourist and recreational resource was depicted in the works of O. Beydyk [3], I. Smyrnov [21], etc. The issues of memorialization of the Holocaust victims in Ukraine were investigated by A. Podol's'kyy [4], V. Nadol's'ka [16], V. Nakonechnyy [17] and others. Domestic research of the mentioned places in Ukraine is carried out at the Ukrainian Center for Holocaust Studies, The Judaica Centre (Kyiv), Tkuma Ukrainian Institute for Holocaust Studies (Dnipro), etc. Foreign authors, such as T. Blom, T. Seaton, K. Rozhek [22], etc., generally, investigate researched sites in the context of dark tourism. The works of A. Shapiro [18], O. Bartov [2], S. Gruber [10] and R. Golbert [6] are devoted to the study of mentioned sites in Ukraine. Foreign researches are carried out by The Yad Vashem's International Institute for Holocaust Research (Israel), The United States Holocaust Memorial Museum (USA), The POLIN Museum of the History of Polish Jews (Poland) etc.

At the same time, mass graves and places of memory of the victims of the Holocaust in the small towns in the Capital socio-geographical region of Ukraine, as a factor of tourism development intensification, require a separate study. This has resulted in the selection of the researched topic.

(C) Maryna Mykhaliuk
Goals. The goal of the article is to analyze the current state of mass graves and places of memory of the victims of the Holocaust of small towns in the Capital socio-geographical region of Ukraine as a component of the ethnocultural potential of the region.

Results and discussion. Traditional culture of a certain ethnic group serves as a tourist resource for the development of various types and forms of tourism. These resources can be divided into existing, which can be demonstrated, and latent, which were inherent to the ethnic groups living in certain territory, and today are not so much represented with material artifacts, but with memories and mentions. Historical memory is significant in determining the latent resource. This notion is not so much mass knowledge about the past, but the perception of the past as an inheritance, which becomes an instrumental value [19, p. 139].

The burial sites are significant if they have historical, social, artistic, religious, genealogical, technological, landscape, botanical or representative value. The most widely accepted definition of mass graves is the group burial of the dead in similar time period, often as a result of the military event, famine, epidemic or natural disaster. The concept of "place of memory" was suggested by P. Nora in the end of 20th century. The philosopher defined it as any existing object, material or non-material in nature, which by dint of human will or the work of time has become a symbolic element of the memorial heritage of any community. Such places may include: places such as museums, cathedrals, mosques, temples, palaces, cemeteries, archives and memorials; concepts and practices such as commemorations, mottos, and all rituals; objects such as inherited property, commemorative monuments, emblems, basic texts, and symbols etc. The concept focuses on the identity of community and covers not only physical remains, but also intangible cultural expressions [8].

In these sense, the memorial legacy covers both material and non-material objects which are components of the ethnocultural potential of a particular territory. The ethnocultural potential of the region is based on the ethnocultural spatial system, representing a set of interconnected components of material and nonmaterial culture, institutions and ethnic groups that interact in the corresponding regional geocultural space [14, p. 113]. The resources of the ethnocultural potential can be divided into historical and cultural, socio-economic, spiritual and cultural, manufacturing and technological, administrative, biosocial [3, p. 69], socio-cultural, innovative and commercial, educational and scientific, national-cultural [15, p. 89], investment and patronage components.

There are a large number of the Jewish mass graves and places of the Holocaust victims' memory in the researched towns. Since July 1940 by June 1941, after the occupation of the interwar Polish and Romanian territories by J. Stalin, the number of Jews in the USSR increased to at least 2.45 million people, making Ukraine the homeland of the largest Jewish minority [5, p. 11]. In 1941, the German invasion of the Soviet Union led to a huge tragedy of Ukrainian Jewry. The murder of the Jewish population in different countries of Europe, 
which was committed by Nazi Germany, with the help of representatives of other occupied countries during the Second World War is called Holocaust. In Hebrew literature the term Shoa (misfortune) is also used. During the Nazi period and during the war, 6 million European Jews were murdered in the 27 countries of the European continent [4, p.58].

Between 1941 and 1944, the German invaders killed about 1.4 million Jews living in the country [7, p. 20]. The main features of the Holocaust in Ukraine were the widespread propaganda of the Jews' accusations in "yids-bolshevism", the massive use of the order of the executions of persons who hid or provided assistance to the Jews. Murder lasted from 1941 to 1944 [5, p. 378]. Many of the victims were deported to death camps, tens of thousands of the Jews were shot in the fields or in the woods. The victims of these murders were often forced to go in large groups to the place of execution, where they usually dug their graves. There is no accurate data on the number of the Holocaust victims in the towns of the studied area, also local tragic dates are often approximate. According to general estimates, most of the Jews were killed in Radomyshl (more than 2000), Skvyra (more than 1000), and Bohuslav (more than 400) [1, 11, 13]. Within the Capital socio-geographical region of Ukraine, the largest number of the mass graves is located in Skvyra, Tarashcha and Bohuslav (Fig. 1).

Within the studied towns, the largest number of memorials, monuments and commemorative plaques to the Holocaust victims are located in Radomyshl, Koriukivka, Bohuslav and Skvyra (Fig. 2). The surrounding monuments were also referred to the towns as they perpetuate the memory of the Jews who were inhabitants of mentioned settlements.

During the Soviet period places of memory of the Holocaust victims in Ukraine were not organized properly. The communist regime did not distinguish the Jews from the total number of the war victims. Therefore, many commemorative plaques, located on the murder sites of entire Jewish communities indicate that "peaceful Soviet citizens" or "victims of fascism" etc. are buried here. This completely reflects the totalitarian policy of Soviet power, based on hiding

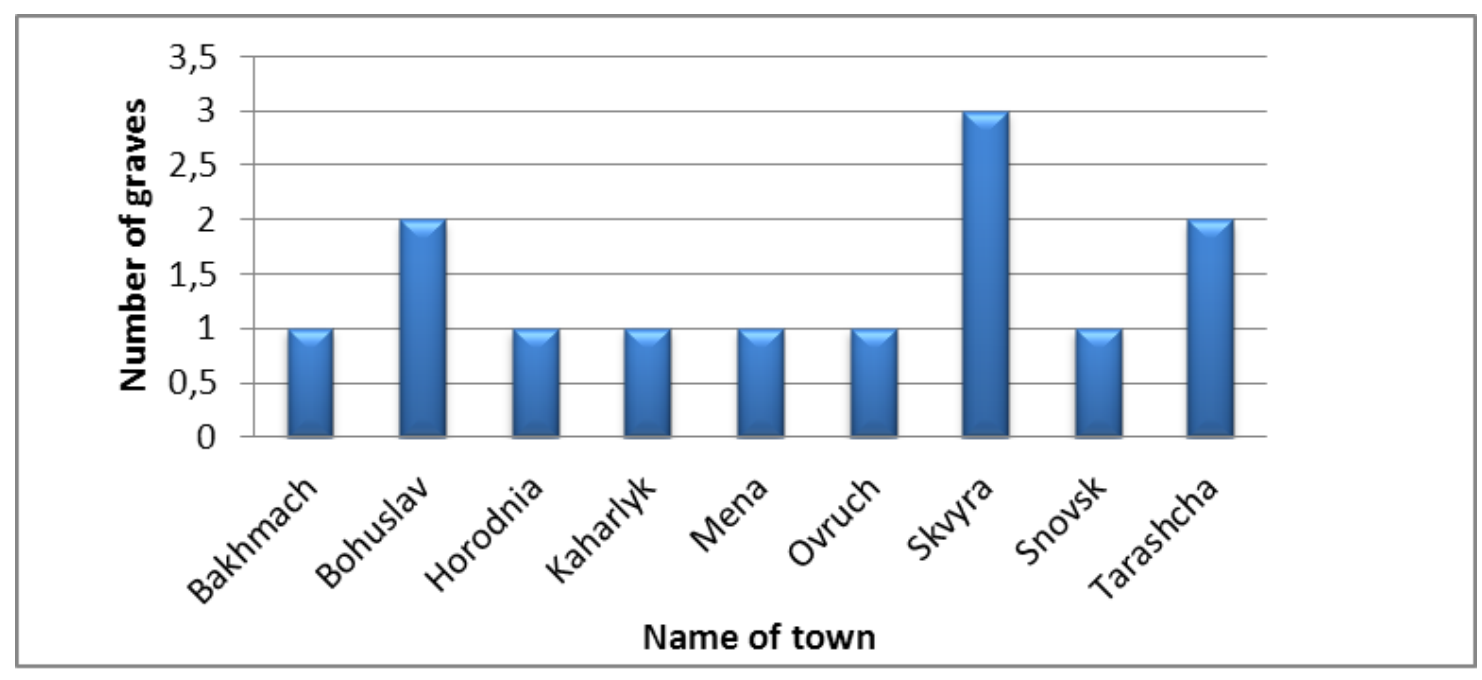

Fig. 1. Number of mass graves of the small towns in the Capital socio-geographical region of Ukraine in 2018 (Own elaboration based on $[9,10,12]$ )

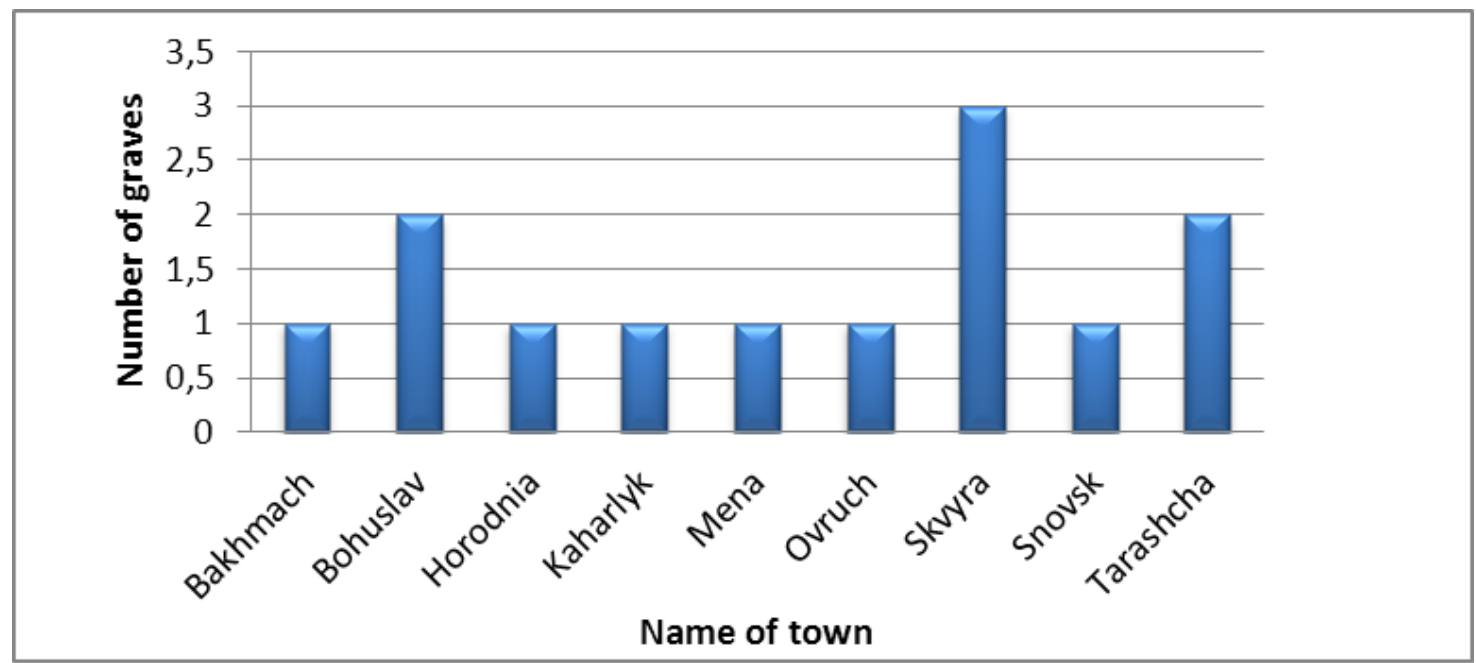

Fig. 2. Number of memorials, monuments and commemorative plaques to the victims of the Holocaust of the small towns in the Capital socio-geographical region of Ukraine in 2018

(Own elaboration based on $[9,10,12,23]$ ) 
the number of the Holocaust victims. After Ukraine gained its independence, the state neither imposed an obstacle to the revival of the memory of the genocide of the Jews, nor participated in it as a rule. For decades, most of the mass killing sites remained neglected and undeclared. Today, there is no state position to preserve the memory of the Holocaust in Ukraine by installing memorial plaques on the mass killing sites of the Jews. The Holocaust history was not integrated into the national narrative of the war. The appearance of monuments to the victims of the Holocaust, the publication of special literature, the arrangement of summer schools and workshops on the Jewish history in Ukraine were the result of public initiatives [4, p. 61]. In 2010, the American Jewish Committee, in cooperation with the Yahad-In Unum Foundation and other partners, launched the Protect the Memory project to preserve and memorize the mass graves. For the pilot project, five places in Western Ukraine were selected: the villages of Bakhiv, Kysylyn, Ostrozhets, Prokhid and the city of Rava-Ruska. The solemn opening of all five memorials took place in 2015 [24].

There are no accurate data on the current state and number of the mass graves and places of memory of the victims of the Holocaust in Ukraine. The most complete data on the number of the Jewish burial sites were provided in 2005 by USA Commission [10]. According to our estimates, there are about $15 \%$ of the Jewish mass graves within the studied towns from their total number in Ukraine. This data is approximate because most of these places are weakly marked or not marked all, so the presence of a memorial with a small plaque reminding of events that have occurred, already describes the condition of the object as relatively satisfactory (Table 1). Given the large number of the Jewish mass graves, the most attention require the

Table 1

Significance and condition of the Jewish mass graves of small towns in the Capital socio-geographical region of Ukraine

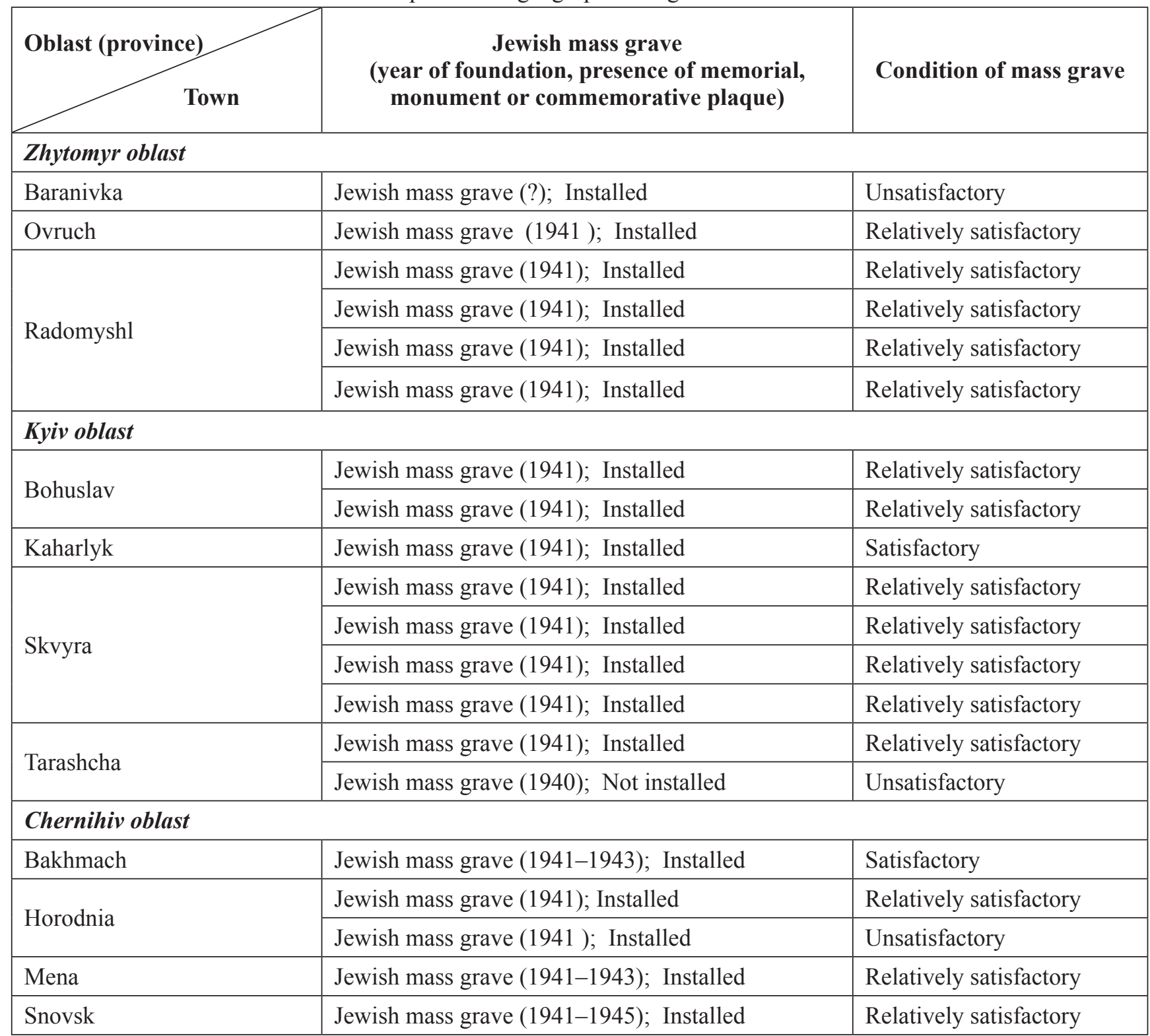


mass graves in Kaharlyk, Horodnia (near the village Aloshynske) - an indication of the Jewish victims on the burial grounds, in Tarashcha (on the territory of the Jewish cemetery), the delineation of the relevant territory, its fencing and marking.

Many places of the tragedy have no memorials. The protection of the mass graves and places of memory remains a burning issue. However, to date, only the sites which are marked as the burial places of "peaceful Soviet citizens" and / or "victims of fascism" have the status of the local heritage. Only $30 \%$ of the monuments from their total number in Ukraine have the protective number. Such monuments are located in Koriukivka, Bakhmach, Ichnia, Kaharlyk, Mena and Novhorod-Siverskyi (Fig. 2). About $80 \%$ of the graves are in a relatively satisfactory condition. The installation of memorials is carried out by non-governmental organizations or private persons.

The Jewish communities of the studied towns at present consist mainly of elderly people and are not numerous, due to the waves of emigration to the western countries, the migration of the population to large cities. The most numerous Jewish communities (from 50 to 100 people) live in Bohuslav, Skvyra and Novhorod-Siverskyi, and in the remaining towns they account for up to 20 people. At the initiative of the communities, important national dates are commemorated, such as the International Holocaust Memorial Day (January 27), the Yomha-Shoa (second half of April or early May), as well as local tragic dates are honoured. There can be various ways to protect and memorialize the Jewish mass graves and places of memory of the Holocaust victims in Ukraine. However, considering the small amount of Jewish inhabitants in studied towns, the communities will not have sufficient resources for abovementioned actions. Therefore, the government programme on protection and memorialization of these sites must be implemented. In addition, nongovernmental initiatives such as the Protect the Memory project should be also involved. The tragedy of the Holocaust deserves deeper consideration in the school curriculum. The history of Holocaust should be integrated into the national narrative of war, and not to be perceived only as part of Jewish history.

The mass graves and places of memory of the Holocaust victims are of great interest, first of all, for those who used to live in these towns, those interested in the history and origin of their families, the descendants of people who survived the Holocaust and those interested in the Jewish legacy. However, these sites are part not only of the Jewish historical memory, but also are an important page of the history of all Ukrainian citizens.

Conclusion and Implications. The scientific analysis of the mass graves and the memorial sites of the victims of the Holocaust in the small towns of the Capital socio-geographical region of Ukraine makes it possible to draw some conclusions and synthesis, as well as to propose prospects for further explorations in the researched topic.

There are a large number of the mass graves and places of memory of the victims of the Holocaust in the studied towns. The majority about $-80 \%$ of the mass graves are in satisfactory condition. At the same time, only those that indicate the burials of "peaceful Soviet citizens" and / or "victims of fascism" have the status of the cultural and historical heritage at the local level. Only $30 \%$ of the monuments from their total number in Ukraine have the protective number. Such monuments are located in Koriukivka, Bakhmach, Ichnia, Kaharlyk, Mena and Novhorod-Siverskyi. The Jewish communities of the studied towns so far are not numerous and mainly consist of elderly people. More than 50-100 people live in Bohuslav, Skvyra and Novhorod-Siverskyi, and in the remaining towns have up to 20 people. Therefore, the ability of communities to maintain and identify places of memory of the victims of the Holocaust is very limited. In many towns, tragic dates are honoured on the initiative of local communities.

There is no clear state position for preservation of the memory of the victims of the Holocaust in Ukraine by installing memorials in places of mass execution of the Jews. The installation of memorials, monuments and commemorative plaques is carried out mainly by nongovernmental organizations or private persons. There are no memorable signs on many places of tragedy, which makes it difficult to hold meetings during tragic dates. Unfortunately, the history of the Holocaust was not integrated into the national narrative of war, so it is still perceived only as part of the Jewish history. However, the memory of the tragic events and the commemoration of the victims is a necessary symbol for present and future generations. At the same time, the mass graves and places of memory of the Holocaust victims constitute an important part of the ethnocultural potential of the region, which can contribute to the development of various types of tourism, and as a result, improve the socio-economic situation in the studied towns. In order to provide required protection and memorialization of these sites, the government programme must be implemented and non-governmental initiatives should be involved. The history of the Holocaust should be integrated into the national narrative of war. Further socio-geographical research of this topic should concern the implementation of the ethnocultural potential of the Jewish ethnos of the studied towns by integrating the history of the Holocaust into the consciousness of society, as well as developing, with the help of leading research and educational institutions, learning programs, primarily for local residents.

\section{References:}

1. Altman I. A. Holokost na territorii SSSR: Enciklopediâ [Holocaust on the territory of the USSR: Encyclopedia]. Moskow, ROSSPEN: Kholokost research centre, 2009, 1143 p. (In Russian).

2. Bartov O. Erased: Vanishing traces of Jewish Galicia in present-day Ukraine. Princeton and Oxford: Princeton University Press, 2007, 232 p. 
3. Beydyk O. O. Rekreacìjnì resursi Ukraïni [Recreational resources of Ukraine]. Kyiv, Altpres, 2010, 404 p. (In Ukrainian).

4. Bobrov V., Holosova N., Pedan-Slyepukhina O., Podol's'kyy A., Tyahlyy M. İstoriâ Golokostu: osvita ta pam'ât'. Posibnik dlâ včitelâ [Holocaust History: Education and Memory. Teacher's Guide]. Kyiv: Ukrainian Centre for Holocaust History, 2006, 124 p. (In Ukrainian).

5. Brandon R., Lauer V. Šoa v Ukraïnì. İstorîa, svìdčennâ, uvičnennâ [Shoa in Ukraine. History, testimonies, perpetuals]. Kyiv, Dukh i Litera, 2015, 520 p.(In Ukrainian).

6. Golbert R. L. Holocaust Sites in Ukraine: Pechora and the Politics of Memorialization. [Electronic source]. Access mode: https://academic.oup. com/hgs/issue/18/2.

7. Hisem, O.V., Martynyuk, O.O. Golokost v Ukraïnì (1941-1944): Slovnik-dovidnik [Holocost in Ukraine (1941-1944): Dictionary-reference book]. Kyiv, Ukrainian Centre for Holocaust History, 2012, 100 p. (In Ukrainian).

8. International Coalition of Sites of Conscience. Interpretation of Sites of Memory. January 31, 2018. [Electronic source]. Access mode: http://whc.unesco.org/en/activities/933/.

9.International Jewish Cemetery Project.[Electronic source]. Accessmode:http://www.iajgsjewishcemeteryproject. org/ukraine/index.html.

10. Jewish cemeteries, synagogues, and mass grave sites in Ukraine (2005). United States Commission for the Preservation of America's Heritage Abroad. [Electronic source]. Access mode: http://www.heritage abroad.gov/ Portals/0/Reports\%20and\%20Surveys/survey_ukraine_2005.pdf?ver=2016-02-24-124109-037.

11. Kruglov, A.I. Hronika Holokosta v Ukraine [Chronicle of the Holocaust in Ukraine]. Zaporizhia, Premier, 2004, 208 p. (In Russian).

12. Lo Tishkach [Electronic source]. Access mode: http://www.lotishkach. org/en/index.php?categoryid=42.

13. Miron G., Berenbaum M. The Yad Vashem Encyclopedia of the Ghettos during the Holocaust in 2 vol. Jerusalem, Yad Vashem, 2009, 500 p.

14. Mykhaliuk M. M. Etnokul'turnyy potentsial yak faktor staloho rozvytku v malykh mistakh Ukrayiny [Ethnocultural potential as a factor of sustainable development in small towns of Ukraine]. Proceedings from the International Scientific and Practical Conference "Region 2017: Optimal Development Strategy". Kharkiv, 2017, pp. 112-114. (In Ukrainian).

15. Mykhaliuk M. M. Komponentna struktura etnokul'turnogo potencìalu regionu [Component structure of ethnocultural potential of the region] Proceedings of the 13 International Scientific Interdisciplinary Conference of students, postgraduates and young scientists "Young scientists for geography". Kyiv, 2017, pp. 87-89. (In Ukrainian).

16. Nadolska V. V. Memorìalìzaciâ mìsc' masovih pohovan' êvreïv perìodu Drugoï svìtovoï vìnni [Memorialization of places mass burial sites of the Volhynian Jews during the Second World War]. Proceedings of LVI Volyn Regional Scientific History and Local History Conference "Past and present of Volyn and Polissya. Necropolis of the land". Lutsk, 2015, pp. 108-112. (In Ukrainian).

17. Nakonechnyy V. A. Holokost na Volini: žertvi ì pam'ât' [The Holocaust in Volhynia: victims and memory]: [Electronic source]. Access mode: http://www.shorashim.narod.ru/case_nakonechniy.htm. (In Ukrainian).

18. Shapiro A. S. Preodolevaâ sovetskoe nasledie: "Mesta pamâti" evreev v gorodskom prostranstve Ukrainy (na primere istoričeskih muzeev i memorialov pamâti žertvam Holokosta) [Overcoming the Soviet legacy: "Places of memory" for Jews in the urban space of Ukraine (on the example of historical museums and memorials to the Holocaust victims)]. Labirint. Zhurnal sotsialno - gumanitarnykh issledovaniy [Labyrinth. Journal of Social and Humanitarian Research], 2003, N. 6, pp. 59-66. (In Russian).

19. Shapoval Yu. Kul'tura istoričnoï pam'âtì: êvropejs'kij ta ukraïns'kij dosvid [Culture of historical memory: European and Ukrainian experience]. Kyiv, IPIEND, 2013, 600 p. (In Ukrainian).

20. Shparaha T. I., Mykhaliuk M. M. Turizm mìscâmi êvrejs'kih zahoronen' v Ukraïnì [Jewish burial ground Tourism in Ukraine]. İstoriâ ukraïns'koï geografiï. Vseukraïns'kij naukovo-teoretičnij časopis [History of Ukrainian Geography: All-Ukrainian Scientific and Theoretical Journal]. Ternopil, 2012, N. 26, pp. 136-140. (In Ukrainian).

21. Smyrnov I. H. Vỉjs'kova logìstika âk turističnij resurs: na prikladì pam'âtok Peršö̈ svitovoï vìjni [Military logistics as a tourist resource: on the example of the sites of the First World War]. Journal of Human Geography, 2014, Vol. 16, pp. 25-32. (In Ukrainian).

22. Stone P., Sharpley R. The Darker Side of Travel - The Theory and Practice of Dark Tourism. Bristol, Channel View Publications, 2009, 275 p. (In English).

23. The Untold stories. The Murder sites of the Jews in the occupied territories of the former USSR. [Electronic source]. Access mode: https://www.yadvashem.org/untoldstories/database/commemoration.asp?cid=947.

24. Zahist ì memorìalizaciâ misc' masovih pohovan' êvrë̈v Ukrä̈ni [Protection and memorialization of mass murder sites of the Jews of Ukraine] : [Electronic source]. Access mode: http://protecting-memory-ua.org/. (In Ukrainian). 


\section{Список використаних джерел:}

1. Бейдик О. О. Рекреаційні ресурси України : Навч. посібн-2-е видання О. О. Бейдик. - К. : Альтпрес, 2010. - 404 с.

2. Гісем О. В. Голокост в Україні (1941-1944): Словник-довідник / О. В. Гісем, О. О. Мартинюк. -Вид.4-е. - К. : Український центр вивчення історії Голокосту, 2012. - 100 с.

3. Захист і меморіалізація місць масових убивств євреїв України. [Електронний ресурс] : [веб-сайт]. Режим доступу: http://protecting-memory-ua.org/. - Назва з екрана.

4. Історія Голокосту: освіта та пам'ять. Посібник для вчителя. - Вид.2- ге, випр. / автори та упор. В. Бобров, Н. Голосова, О. Педан-Слєпухіна, А. Подольський, М. Тяглий. - К. : Український центр вивчення історії Голокосту, 2016. - 124 с.

5. Круглов А. И. Хроника Холокоста в Украине / А. И. Круглов. - Запорожье: Премьер, 2004. - 208 с.

6. Культура історичної пам'яті: європейський та український досвід / за заг. ред. Ю. Шаповала. - К.: ІПІЕНД, 2013. - 600 с.

7. Михалюк М. М. Етнокультурний потенціал як фактор сталого розвитку в малих містах України / М. М. Михалюк / Регіон-2017: стратегія оптимального розвитку: матеріали міжнародної науково-практичної конференції (м. Харків, 19-20 вересня 2017 р.). - Х. : ХНУ імені В. Н. Каразіна. - 2017. - С. $112-114$.

8. Михалюк М. М. Компонентна структура етнокультурного потенціалу регіону / М. М. Михалюк // Молоді вчені географічній науці : Збір. наук. праць ХІІІ міжнародної наукової міждисциплінарної конференції студентів, аспірантів і молодих вчених. - К. : Принт Сервіс. - 2017. - Вип. XIII. - С. 87-89.

9. Надольська В. В. Меморіалізація місць масових поховань євреїв Волині періоду Другої світової війни / В. В. Надольська // Минуле і сучасне Волині та Полісся. Некрополі краю. Науковий збірник Вип. 56. Матеріали LVI Волинської обласної наукової історико-краєзнавчої конференції (м. Луцьк 25 листопада 2015 р.). - Луцьк : ВОО НСКУ, 2015. - С. 108-112.

10. Наконечный В. А. Холокост на Волыни: жертвы и память [Электронный ресурс] / В. А. Наконечный // Корни: публицистический и культурно-просветительский журнал русскоговорящих еврейских общин : [веб-сайт]. - Режим доступу: http://www.shorashim. narod.ru/case nakonechniy.htm. - Назва 3 екрана.

11. Смирнов I. Г. Військова логістика як туристичний ресурс: на прикладі пам’яток Першої світової війни / І. Г. Смирнов // Часопис соціально-економічної географії. - 2014. - Вип. 16. - С. 25-32.

12. Холокост на территории СССР: Энциклопедия / Гл. ред. И. А. Альтман. - М. : РОССПЭЕН: научно-просветительский центр «Холокост», 2009. -1143 с.

13. Шапиро А.С. Преодолевая советское наследие: «Места памяти» евреев в городском пространстве Украины (на примере исторических музеев и мемориалов памяти жертвам Холокоста) / А. С. Шапиро // Лабиринт. Журнал социально-гуманитарных исследований. - 2003. - Вип. 6. - С. 59-66.

14. Шоа в Україні. Історія, свідчення, увічнення / За ред. Р. Брандона, В. Лауер. - К. : ДУХ і ЛІТЕРА, 2015. - 520 с.

15. Шпарага T.I. Туризм місцями єврейських захоронень в Україні / Т. І. Шпарага, М. М. Михалюк // Історія української географії: всеукраїнський науково-теоретичний часопис. - 2012. - Вип. 26. - С. $136-140$.

16. Bartov O. Erased: Vanishing traces of Jewish Galicia in present-day Ukraine / O. Bartov. - Princeton and Oxford: Princeton University Press, 2007. - 232 p.

17. Golbert R. L. Holocaust Sites in Ukraine: Pechora and the Politics of Memorialization [Electronic source] : [web-site]. - Mode of access: https://academic.oup.com/hgs/issue/18/2. - Title from the screen.

18. International Coalition of Sites of Conscience Interpretation of Sites of Memory January 31 - 2018 [Electronic source] : UNESCO : [web-site]. - Mode of access: http:// whc.unesco.org/en/activities/933/. - Title from the screen.

19. International Jewish Cemetery Project [Electronic source] : [web-site]. - Mode of access: http://www. iajgsjewishcemeteryproject.org/ukraine/ index.html. - Title from the screen.

20. Jewish cemeteries, synagogues, and mass grave sites in Ukraine (2005) [Electronic source] / United States Commission for the Preservation of America's Heritage Abroad : [web-site]. - Mode of access: http://www. heritage abroad.gov/Portals/0/Reports\%20and\%20Surveys/survey_ukraine_2005.pdf?ver=2016-02-24-124109-037. - Title from the screen.

21. Lo Tishkach [Electronic source] : [web-site]. - Mode of access: http://www. lotishkach.org/en/index. php?categoryid=42. - Title from the screen.

22. Miron G. The Yad Vashem Encyclopedia of the Ghettos during the Holocaust in 2 vol. / G. Miron, M. Berenbaum. - Jerusalem: Yad Vashem, 2009. -500 p.

23. Stone P. Making Absent Death Present: Consuming Dark Tourism in Contemporary Society / P. Stone, R. Sharpley // The Darker Side of Travel - The Theory and Practice of Dark Tourism. - Bristol: Channel View Publications, 2009. - 288 p.

24. The Untold stories. The Murder sites of the Jews in the occupied territories of the former USSR [Electronic source] : Yad Vashem. The World Holokaust Remembrance Centre : [web-site]. - Mode of access: https://www.yadvashem.org/untoldstories/database/commemoration.asp?cid=947. - Title from the screen. 